\title{
PENGARUH RESOLUSI SPASIAL CITRA TERHADAP HASIL PEMETAAN KANDUNGAN HARA NITROGEN PERKEBUNAN KARET
}

\author{
The Effect of Spatial Resolution Image on \\ The Results of Nitrogen Content Mapping of Rubber Plantation \\ Jamin SAPUTRA ${ }^{1,2, *}$, Muhammad KAMAL ${ }^{2}$, dan Pramaditya WICAKSONO ${ }^{2}$ \\ ${ }^{1}$ Balai Penelitian Sembawa, Pusat Penelitian Karet \\ Jalan Raya Palembang - P. Balai KM 29 PO BOX 1127 \\ Palembang 30001 Sumatera Selatan \\ *Email: jamincomsu@yahoo.com \\ ${ }^{2}$ Program Studi S2 Penginderaan Jauh, Fakultas Geografi, UGM \\ Bulaksumur Yogyakarta 55281
}

Diterima : 3 April 2018 / Disetujui : 30 Mei 2018

\begin{abstract}
Nitrogen is one of the nutrients needed in large quantities by plants. Plant with nitrogen deficiency will lead to stunted growth and decreased plant productivity. Implementation of the precision farming system on fertilizer activity in rubber plantation was done by determining fertilizer dose that is made based on soil and plants nutrient content. For large areas, it is costly analysis of plant nutrients. Therefore it is needed a technology that can estimate the condition of plant nutrients quickly and low cost. Remote sensing technology is an alternative that can be used for large areas and with a fast time and it is relatively low cost. The study was aimed to obtain information effect of spatial resolution images on the results of nitrogen content mapping on rubber plantation. Multi-resolution images used include GeoEye-1 (2 m), Sentinel-2A (10 and $20 \mathrm{~m}$ ), and Landsat 8 OLI $(30 \mathrm{~m})$. The method used was to build semi-empirical relationship between single band and image vegetation index with rubber plant nitrogen nutrient content. The results showed that map of nitrogen content estimate of rubber plant using Sentinel-2A (SE 0,369) image had higher accuracy than using GeoEye-1 (SE $0,519)$ and Landsat 8 OLI images (SE 0,462).
\end{abstract}

Keywords: Nitrogen; remote sensing; rubber plantations; vegetation index
Abstrak

Nitrogen merupakan salah satu unsur hara yang dibutuhkan dalam jumlah banyak oleh tanaman. Tanaman yang mengalami kekurangan unsur hara nitrogen akan menyebabkan terhambatnya pertumbuhan dan penurunan produktivitas tanaman. Penerapan sistem pertanian presisi pada kegiatan pemupukan di perkebunan karet dilakukan dengan cara dosis pemupukan dibuat berdasarkan kandungan hara tanah dan kandungan hara pada tanaman. Pada areal yang luas membutuhkan biaya analisis hara tanaman yang cukup mahal. Oleh karena itu sangat dibutuhkan suatu teknologi yang dapat mengestimasi kondisi hara tanaman dengan cepat dan biaya yang murah. Teknologi penginderaan jauh merupakan alternatif yang dapat digunakan untuk areal yang luas dan dengan waktu yang cepat serta biaya yang relatif murah. Penelitian ini bertujuan untuk mengetahui pengaruh resolusi spasial citra terhadap peta hasil estimasi kandungan hara nitrogen perkebunan karet. Citra multi resolusi yang digunakan antara lain GeoEye-1 (2 m), Sentinel-2A (10 dan 20 $\mathrm{m})$ dan Landsat 8 OLI $(30 \mathrm{~m})$. Metode yang digunakan adalah membangun hubungan semi-empiris antara band tunggal dan indeks vegetasi citra dengan kandungan hara nitrogen perkebunan karet. Hasil penelitian menunjukkan bahwa peta hasil estimasi kandungan hara nitrogen 
perkebunan karet menggunakan citra Sentinel-2A (SE 0,369) memiliki akurasi yang lebih tinggi dibandingkan dengan menggunakan citra GeoEye- 1 (SE 0,519) dan Landsat 8 OLI (SE 0,462).

Kata kunci: Indeks vegetasi; nitrogen; penginderaan ja $\mathrm{uh}$; perkebunan karet

\section{PENDAHULUAN}

Karet merupakan salah satu komoditas penting sub-sektor perkebunan di Indonesia karena karet telah menjadi sumber devisa negara, sumber mata pencaharian penduduk, dan pelestari lingkungan. Pada tahun 2013, komoditas karet menghasilkan devisa sebesar USD 6,9 Milyar (Gabungan Perusahaan Karet Indonesia [Gapkindo], 2014) dan diperkirakan pada tahun 2017 menjadi sumber mata pencaharian $\pm 2,5$ juta keluarga petani (Direktorat Jenderal Perkebunan [Ditjenbun], 2016).

Nitrogen $(\mathrm{N})$ merupakan hara makro utama yang sangat penting untuk pertumbuhan tanaman (Rosmarkam \& Yuwono, 2002). Unsur hara $N$ bagi tanaman berperan untuk pertumbuhan vegetatif (pertumbuhan daun dan batang), meningkatkan kadar protein tanaman, juga untuk berkembangnya mikroorganisme dalam tanah (Indranada, 1994). Kekurangan (defisiensi) hara nitrogen mengakibatkan terhambatnya pertumbuhan dan menurunkan produksi tanaman karet. Kandungan hara nitrogen pada tanaman karet dapat mempengaruhi produksi lateks karena apabila terjadi kekurangan kandungan hara nitrogen akan mengganggu aktivitas fotosintesis. Lateks merupakan produk sekunder hasil fotosintesis tanaman karet (Thomas \& Hidayati, 2003). Hasil penelitian menunjukkan bahwa pada kondisi kandungan hara nitrogen tanaman karet rendah $(3,08 \%)$ mengakibatkan terhambatnya pertumbuhan kulit pulihan dan penurunkan produksi (Wijaya, Ardika, \& Saputra, 2014).

Efisiensi pemupukan dapat dilakukan dengan cara memberikan dosis pupuk sesuai dengan kebutuhan tanaman dan kandungan hara yang terkandungan pada tanah, sehingga dosis rekomendasi pemupukan disusun dengan mempertimbangkan kandungan hara tanah dan tanaman. Oleh karena itu, perlu dilakukan analisis tanah dan daun tanaman pada luasan tertentu yang sering disebut blok contoh atau LSU (Leaf Sampling Unit). Metode penentuan kebutuhan pupuk saat ini membutuhkan waktu lama dan biaya yang mahal karena LSU yang dibuat hanya untuk 40-60 Ha tanaman dengan umur dan jenis klon yang sama, sehingga untuk areal yang luas membutuhkan biaya analisis tanah dan tanaman yang cukup mahal. Oleh karena itu sangat dibutuhkan suatu teknologi yang dapat mengestimasi kondisi hara tanaman dengan cepat dan biaya yang murah sehingga pemupukan dapat diberikan berdasarkan kebutuhan tanaman.

Berkembangnya teknologi penginderaan jauh (satelit dengan berbagai resolusi) dan sistem informasi geografis membuat manajemen lahan secara spasial dapat dikelola dengan mudah dan cepat. Estimasi kandungan hara nitrogen dengan menggunakan citra penginderaan jauh multispektral pada tanaman semusim telah dilakukan beberapa peneliti diantaranya pada tanaman jagung menggunakan citra Quickbird (Bausch \& Khosla, 2010), pada tanaman gandum menggunakan citra Ikonos (Jia et al., 2011) dan pada tanaman gandum menggunakan citra RapidEye (Basso et al., 2016; Magney et al., 2016). Hasil penelitian tersebut menunjukkan bahwa nilai koefisien determinasi $\left(R^{2}\right)$ lebih dari 0,70. Hal tersebut menunjukkan bahwa penggunaan citra penginderaan jauh juga berpotensi digunakan untuk mengestimasi kandungan nitrogen pada tanaman perkebunan.

Saat ini terdapat beberapa pilihan citra penginderaan jauh yang memiliki resolusi tinggi hingga sedang. Citra resolusi tinggi seperti GeoEye-1 memiliki resolusi spasial $2 \mathrm{~m}$. Citra dengan resolusi sedang seperti Sentinel-2A dengan resolusi spasial 10 dan $20 \mathrm{~m}$, Landsat 8 OLI dengan resolusi spasial $30 \mathrm{~m}$. Penelitian ini bertujuan untuk memetakan dan mengetahui pengaruh resolusi spasial citra terhadap akurasi pemetaan kandungan hara nitrogen perkebunan karet hasil pemodelan menggunakan citra GeoEye-1, Sentinel-2A dan Landsat 8 OLI. 


\section{BAHAN DAN METODE}

\section{Lokasi dan Data Penelitian}

Penelitian ini dilakukan di Kebun Percobaan Balai Penelitian Sembawa yang terletak pada $2^{\circ} 57^{\prime} 30^{\prime \prime}-2^{\circ} 59^{\prime} 30^{\prime \prime}$ LS dan $104^{\circ} 28^{\prime} 45^{\prime \prime}$ - $104^{\circ} 31^{\prime} 15^{\prime \prime}$ BT. Secara administrasi terletak di Desa Lalang Sembawa, Kecamatan Sembawa, Kabupaten Banyuasin, Provinsi Sumatera Selatan. Penelitian menggunakan citra multi resolusi diantaranya citra GeoEye-1 (2 m) perekaman tanggal 22 Februari 2017, Sentinel-2A (10 dan $20 \mathrm{~m}$ ) perekaman tanggal 5 Desember 2016 dan Landsat 8 OLI $(30 \mathrm{~m})$ perekaman tanggal 19 November 2016.

Pada citra Landsat 8 OLI, Sentinel-2A dan GeoEye-1 yang digunakan dalam penelitian ini tidak dilakukan koreksi geometrik. Hal tersebut dikarenakan menurut USGS (2016) citra Landsat 8 OLI telah terkoreksi geometrik. European Space Agency (2015) juga menginformasikan bahwa citra Sentinel-2A yang digunakan adalah level 1C yang telah terkoreksi geometrik. Citra GeoEye-1 juga telah terkoreksi geometrik(GeoEye, 2009).

Nilai piksel citra Landsat 8 OLI dan GeoEye-1 dalam bentuk digital numbers (DN) dikonversi ke top-of-atmosphere (TOA) spectral radiance (W/ $\left.\mathrm{cm}^{2} \mathrm{~s} \mathrm{r} . \mathrm{nm}\right)$ menggunakan software ENVI. Proses konversi ini dilakukan mengikuti prosedur dan koefisien koreksi dari USGS (2016) untuk citra Landsat 8 OLI. Pada citra GeoEye-1 menggunakan rumus koreksi dari Kuester (2017) untuk mengubah DN ke radian dan dari radian ke TOA menggunakan rumus dari Updike dan Comp (2010). Selanjutnya koreksi atmosferik dilakukan untuk mengubah data dari format reflektan TOA menjadi BOA (Bottom of Atmosphere). Metode yang digunakan adalah metode Dark Object Subtraction (DOS)

(Chavez, 1996). Pada citra GeoEye-1, Sentinel-2A, dan Landsat 8 OLI tidak terdapat dark object yang ideal seperti air dalam dan jernih sehingga digunakan metode DOS dengan cara pengurangan nilai reflektan TOA dengan nilai minimal pada setiap band citra yang digunakan. Hal tersebut berdasarkan hasil penelitian Wicaksono dan Hafizt (2017) yang menunjukkan bahwa nilai minimum pada setiap band citra dapat digunakan pada kondisi dark object yang tidak ideal.

Citra GeoEye-1 dengan resolusi spasial citra $2 \mathrm{~m}$ dilakukan resampling citra menjadi resolusi spasial 4, 6, 8, dan $10 \mathrm{~m}$. Resampling juga dilakukan pada citra Sentinel-2A untuk band dengan resolusi spasial $10 \mathrm{~m}$ menjadi $20 \mathrm{~m}$. Metode resampling yang dilakukan adalah cubic convolution.

\section{Metode Pengumpulan Data Penelitian}

Hasil penelitian sebelumnya menunjukkan bahwa indeks vegetasi yang menggunakan band Green, Red, Red-Edge dan NIR merupakan indeks vegetasi yang sensitif terhadap kandungan klorofil tanaman (Yoder \& Pettigrew-Crosby, 1995; Daughtry et al., 2000; Haboudane et al., 2002; Baret et al., 2007), sehingga band tunggal yang digunakan adalah Green, Red, Red-Edge dan NIR yang terdapat pada citra GeoEye-1, Sentinel-2A dan Landsat 8 OLI. Indeks vegetasi yang digunakan disajikan pada Tabel 1 .

Lokasi pengambilan sampel ditentukan berdasarkan peta LSU pada lokasi penelitian. LSU menjadi dasar dalam penentuan lokasi sampel karena manajemen pemupukan baik jenis maupun dosis pupuk di lokasi penelitian berdasarkan analisis hara tanah dan tanaman pada setiap LSU. Sampel daun tanaman karet di lapangan diambil dengan metode stratified random sampling. Jumlah sampel sebanyak 50 plot sampel. Jumlah sampel tersebut digunakan untuk membuat model sebanyak 30 sampel dan untuk uji akurasi model sebanyak 20 sampel (Gambar 1). Pada setiap plot sampel diambil sampel daun pada setiap tanaman sehat dan kemudian dianalisis kandungan hara nitrogen dan klorofil di Laboratorium. 
Tabel 1. Indeks vegetasi yang digunakan dalam estimasi kandungan hara nitrogen Table 1. Vegetation index used in the estimation of nutrient nitrogen content

\begin{tabular}{|c|c|c|c|c|}
\hline No. & $\begin{array}{l}\text { Indeks vegetasi } \\
\text { Vegetation Index }\end{array}$ & $\begin{array}{l}\text { Singkatan } \\
\text { Acronym }\end{array}$ & $\begin{array}{l}\text { Rumus } \\
\text { Formula }\end{array}$ & $\begin{array}{l}\text { Referensi } \\
\text { Reference }\end{array}$ \\
\hline 1. & $\begin{array}{l}\text { Normalized Differenced } \\
\text { Vegetation Index }\end{array}$ & NDVI & $\begin{array}{l}(\mathrm{NIR}-\mathrm{Red}) / \\
(\mathrm{NIR}+\mathrm{Red})\end{array}$ & Tucker (1979) \\
\hline 2. & $\begin{array}{l}\text { Green Normalized } \\
\text { Difference Vegetation } \\
\text { Index }\end{array}$ & GN & $\begin{array}{l}(\text { NIR-Green)/ } \\
(\text { NIR+ Green) }\end{array}$ & Gitelson et al \\
\hline 3. & Chlorophyll Index-Green & CI & (NIR/ Green)-1 & Gitelson et al. (2003) \\
\hline 4. & $\begin{array}{l}\text { Optimized Soil Adjusted } \\
\text { Vegetation Index }\end{array}$ & OSAVI & $\begin{array}{l}(\mathrm{NIR}-\mathrm{Red}) / \\
(\mathrm{NIR}+\mathrm{Red}+0,16)\end{array}$ & $\begin{array}{l}\text { Rondeaux et al. } \\
\text { (1996) }\end{array}$ \\
\hline 5. & $\begin{array}{l}\text { Normalized Difference } \\
\text { Red-Edge Index }\end{array}$ & NDRE & $\begin{array}{l}(\mathrm{NIR}-R e d E d g e / \\
(\mathrm{NIR}+\text { Red Edge) }\end{array}$ & $\begin{array}{l}\text { Gitelson \& Merzlyak } \\
\text { (1994) }\end{array}$ \\
\hline
\end{tabular}

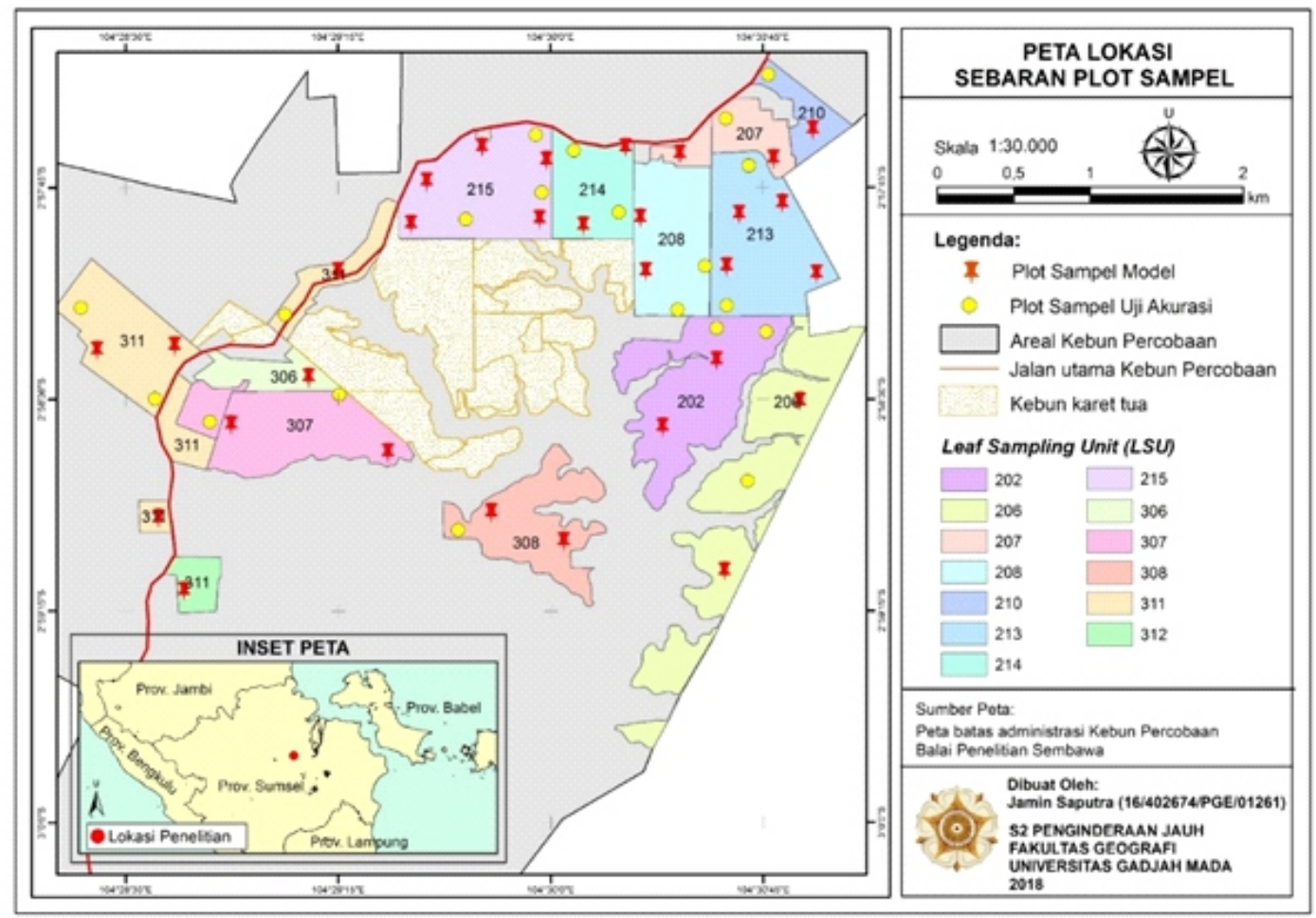

Gambar 1. Sebaran plot sampel untuk membuat model dan untuk uji akurasi Figure 1. The distribution of the sample plot to make the model and to test the accuracy

Ukuran plot sampel mengacu pada Standar Nasional Indonesia (SNI) 7724:2011 (Badan Standarisasi Nasional [BSN], 2011) untuk pengamatan tingkatan pertumbuhan vegetasi pohon ukuran plot sampel lapangan adalah $20 \times 20 \mathrm{~m}$. Pada plot sampel tersebut terdapat \pm 28 tanaman karet. Sampel daun tanaman diambil pada semua tanaman sehat yang terdapat dalam plot tersebut. Menurut Sudiharto et al (2006) pelaksanaan pengambilan contoh daun dibedakan antara tanaman TBM dan TM. Perbedaan posisi, umur daun, payung, dan cabang pada pengambilan daun dapat dilihat pada Tabel 2. Setiap pohon sampel diambil dua tangkai daun yang sehat. Waktu pengambilan sampel daun tanaman pada setiap plot dilakukan pada bulan Desember tahun 2017. 
Tabel1. Indeks vegetasi yang digunakan dalam estimasi kandungan hara nitrogen Table 1. Vegetation indexwas used in the estimation of nutrient nitrogen content

\begin{tabular}{|c|c|c|}
\hline $\begin{array}{l}\text { Ketentuan } \\
\text { Conditions }\end{array}$ & $\begin{array}{l}\text { Tanaman menghasilkan } \\
\text { Mature rubber tree }\end{array}$ & $\begin{array}{l}\text { Tanaman belum menghasilkan } \\
\text { Im mature rubber tree }\end{array}$ \\
\hline Posisi & $\begin{array}{l}\text { Daun diambil pada posisi terlindung } \\
\text { dari sinar matahari }\end{array}$ & $\begin{array}{l}\text { Daun diambil pada posisi terkena } \\
\text { sinar matahari }\end{array}$ \\
\hline Umur & Sekitar 3-6 bulan & Sekitar 3-4 bulan \\
\hline Payung & Daun diambil di payung pertama & $\begin{array}{l}\text { Daun diambil pada payung kedua } \\
\text { dan tidak sedang membentuk daun } \\
\text { baru }\end{array}$ \\
\hline Cabang & $\begin{array}{l}\text { Daun tidak boleh diambil pada tunas } \\
\text { yang tumbuh dari cabang utama }\end{array}$ & Daun diambil pada ranting terakhir \\
\hline
\end{tabular}

Sumber (Source): Sudiharto et al. (2006)

Metode yang digunakan untuk analisis kandungan hara nitrogen adalah metode pengabuan basah dengan $\mathrm{H}_{2} \mathrm{SO}_{4}$ dan $\mathrm{H}_{2} \mathrm{O}_{2}$ dan ditambah dengan metode Kjeldahl (Balai Penelitian Tanah [Balit Tanah], 2009). Analisis kandungan klorofil tanaman dilakukan dengan metode pengukuran spektrofotometer UV-VIS. Setelah dari lapangan sampel daun tanaman karet segera dimasukkan ke Laboratorium Fisiologi. Sampel daun diambil seluas $1 \mathrm{~cm}^{2}$ pada masing-masing plot sampel di lapangan dan dilakukan pengulangan sebanyak tiga kali. Kemudian sampel daun tersebut digunting kecil-kecil dan dimasukkan ke dalam tabung reaksi dan kemudian ditutup. Tabung reaksi tersebut sebelumnya telah dimasukkan pelarut metanol $100 \%$ sebanyak $10 \mathrm{ml}$. Tabung reaksi yang telah berisi sampel daun tersebut di tutup dengan aluminium foil dan dimasukkan ke dalam lemari pendingin sampai klorofil pada sampel daun terlarut semua. Waktu yang dibutuhkan untuk melarutkan semua klorofil daun tanaman karet sampai warna daun berwarna putih selama satu minggu. Ekstrak klorofil kemudian diukur absorbansinya pada panjang gelombang $652 \mathrm{~nm}$ dan $665 \mathrm{~nm}$ dengan menggunakan spektrofotometer UVVIS dan dihitung dengan rumus (Lichtenthaler \& Welburn, 1983) sebagai berikut:

Klorofil $\mathrm{a}=(16,29 \times \mathrm{A665})-(8,54 \times \mathrm{A652})$

…............................................(1)

Klorofil b $=(30,66 \times$ A652 $)-(13,58 \times$ A665 $)$

Klorofil total $=(22,12 \times$ A652 $)+(2,71 \times$ A665 $)$

Keterangan (Remaks) :

A652 dan A665 merupakan nilai absorbansi hasil pembacaan spektrofotometer UV-VIS.

\section{Analisis Data Penelitian}

Analisis statistik yang digunakan untuk mengetahui hubungan band tunggal dan beberapa indeks vegetasi terhadap kandungan hara nitrogen perkebunan karet adalah analisis korelasi dan regresi. Koefisien korelasi menunjukkan derajat kekuatan hubungan nilai indeks vegetasi terhadap kandungan hara nitrogen perkebunan karet hasil analisis sampel daun tanaman di laboratorium. Nilai indeks vegetasi sebagai variabel bebas (X) kandungan hara nitrogen perkebunan karet sebagai variabel terikat (Y). Sebelum uji korelasi dan regresi, dilakukan uji normalitas untuk mengetahui apakah data variabel bebas yang digunakan terdistribusi secara normal atau tidak. Hasil korelasi antara band tunggal dan indeks vegetasi dengan data kandungan hara nitrogen menghasilkan nilai $r$ dan $R^{2}$. Interpretasi koefisien korelasi ditentukan sesuai dengan pedoman yang ditulis oleh Sugiyono (2014) sebagai berikut :

- Korelasi sangat rendah : $0-0,19$

- Korelasi rendah :0,20-0,39

- Korelasi sedang :0,40-0,59

- Korelasikuat :0,60-0,79

- Korelasi sangat kuat : $0,80-1,00$

Analisis regresi digunakan untuk memodelkan kandungan hara nitrogen perkebunan karet menggunakan data penginderaan jauh dengan model semi empiris. Masukan untuk analisis regresi ada1ah nilai-nilai piksel perkebunan karet dari band tunggal dan indeks vegetasi hasil transformasi citra GeoEye-1, Sentinel-2A dan Landsat 8 OLI. Peta estimasi kandungan hara nitrogen perkebunan karet dibuat 
berdasarkan hasil analisis regresi baik itu linear maupun non-linear. Model regresi terbaik dari masing-masing citra digunakan untuk membuat peta estimasi kandungan hara nitrogen. Pemilihan model regresi yang terbaik berdasarkan nilai SE paling rendah pada masing-masing citra.

Uji akurasi model estimasi dilakukan dengan membandingkan 20 plot sampel lapangan independen berisi pengukuran kandungan hara nitrogen perkebunan karet dengan piksel citra pada koordinat yang sama dengan plot sampel di lapangan yang memuat nilai kandungan hara nitrogen perkebunan karet hasil estimasi, dan hasilnya dinyatakan dalam Standard Error of Estimate (SE). Algoritma SE seperti ditunjukkan pada persamaan berikut:

$\mathrm{SE}=\sqrt{\frac{\sum\left(y-y^{\prime}\right)^{2}}{N-2}}$

Keterangan (Remaks):

SE : Nilai estimasi standard error

y : Kandungan hara nitrogen perkebunan karet hasil analisis di laboratorium

$\mathrm{y}^{\prime}$ : Kandungan hara nitrogen perkebunan karet hasil estimasi

$\mathrm{N}$ : Jumlah sampel yang digunakan untuk uji akurasi sebanyak 20 sampel

\section{HASIL DAN PEMBAHASAN}

Kandungan hara nitrogen menunjukkan rentang nilai antara 2,02 $3,77 \%(\mathrm{n}=50$, rata-rata $=2,63 \%$, standar deviasi =0,43). Menurut Adiwiganda et al (1994) kandungan hara nitrogen tanaman karet tersebut dari 50 sampel terdapat 3 sampel tergolong optimum $(3,30-3,50 \%), 2$ sampel tergolong tinggi $(>3,50 \%)$, dan 45 sampel tergolong rendah $(<3,30 \%)$. Banyakya sampel yang kandungan haranya rendah karena dosis pemupukan pada tahun 2015 dan 2016 yang diberikan hanya $50 \%$ dari dosis rekomendasi. Kandungan klorofil berkisar antara 5,07-9,71 mg/L (n $=50$, rata-rata $=7,39 \mathrm{mg} / \mathrm{L}$, standar deviasi $=1,02)$. Pengukuran kandungan klorofil bertujuan untuk mengetahui hubungan kandungan nitrogen dengan kandungan klorofil tanaman. Korelasi antara kandungan klorofil dengan nitrogen tanaman (Gambar 2) menunjukkan hubungan yang kuat $\left(R^{2}=0,86\right)$. Hubungan yang kuat tersebut menunjukkan bahwa estimasi kandungan nitrogen tanaman dapat dilakukan dengan menggunakan citra penginderaan jauh, karena band Green, RedEdge, dan NIR merupakan band yang sensitif terhadap kandungan klorofil tanaman(Yoder \& Pettigrew-Crosby, 1995; Daughtry et al., 2000; Haboudane et al., 2002; Baret et al., 2007).

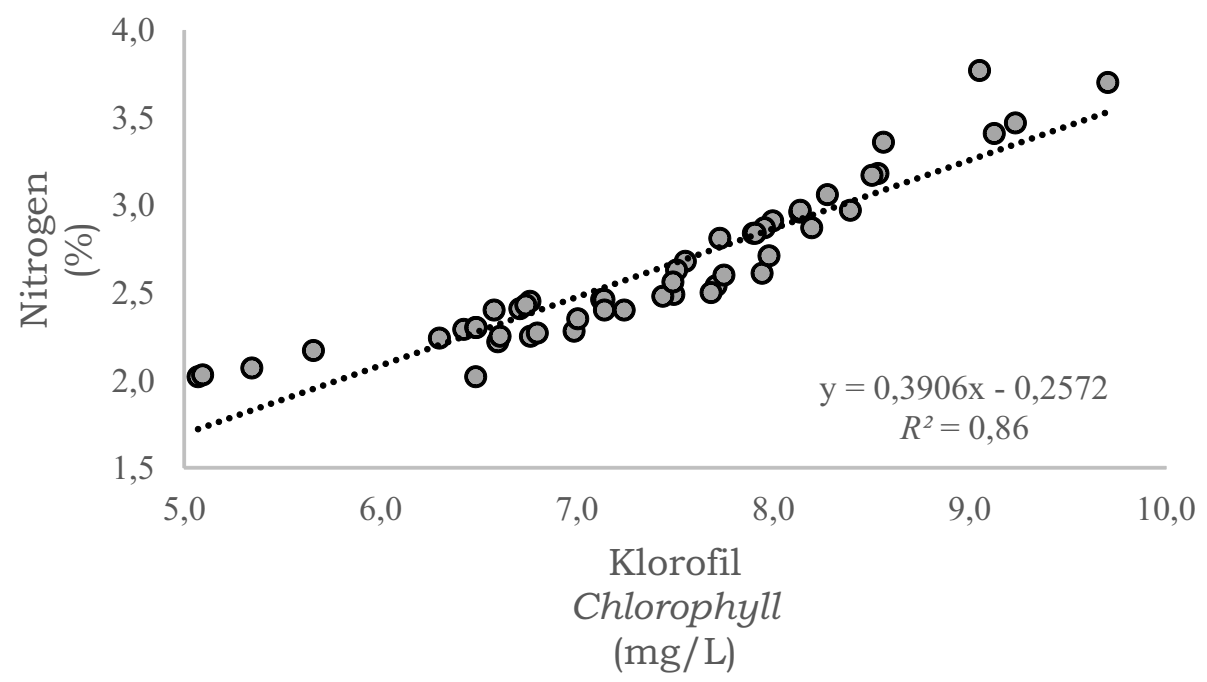

Gambar 2. Hubungan kandungan hara nitrogen dengan klorofil Figure 2. Correlation of nitrogen nutrient content and chlorophyll 


\section{Analisis Hubungan Beberapa Band Tunggal dan Indeks Vegetasi terhadap Kandungan Hara Nitrogen Perkebunan Karet}

Hasil uji korelasi band tunggal dan indeks vegetasi dari citra GeoEye-1 menunjukkan tidak ada korelasi yang signifikan dengan kandungan nitrogen perkebunan karet maka dilakukan resampling citra. Proses resampling dilakukan dengan metode cubic convolution. Metode nearest neighbour tidak dilakukan karena diperlukan untuk melihat efek informasi spektral baru pada setiap piksel. Hal tersebut baik untuk citra dengan kontribusi latar belakang tinggi atau citra dengan noise tinggi (Wicaksono, 2017). Resampling juga dilakukan pada citra Sentinel-2A untuk band resolusi spasial 10 $\mathrm{m}$ menjadi $20 \mathrm{~m}$.

Hasil uji korelasi dan regresi terbaik pada masing-masing citra disajikan pada Tabel 3. Hasil tersebut menunjukkan bahwa hanya indeks vegetasi CI dari citra Sentinel2A memiliki hubungan yang kuat $(r=0,60)$ dengan kandungan hara nitrogen tanaman. Korelasi tertinggi pada citra GeoEye- 1 hanya 0,47 dan pada citra Landsat 8 OLI hanya 0,42 .

Rendahnya nilai $R^{2}$ kemungkinan dikarenakan jarak antara waktu perekaman citra dengan waktu pengambilan sampel di lapangan terlalu jauh. Waktu perekaman citra GeoEye-1 tanggal 22 Februari 2017, citra Sentinel-2A tanggal 19 November 2016, dan citra Landsat 8 OLI tanggal 05 Desember 2016. Waktu pengambilan sampel di lapangan dilakukan pada tanggal 11-21 Desember 2017, sehingga selisih antara waktu perekaman dengan pengambilan sampel sekitar 10 bulan dengan citra GeoEye-1, sekitar 13 bulan dengan citra Sentinel-2A, dan sekitar 12 bulan dengan citra Landsat 8 OLI. Pemilihan waktu perekaman citra idealnya berdekatan dengan waktu pengambilan sampel di lapangan, namun sampai dengan bulan Januari 2018 perekaman citra Sentinel-2A dan Landsat 8 OLI pada lokasi penelitian tidak terdapat citra yang tutupan awannya rendah.

Faktor lain yang mungkin menyebabkan rendahnya korelasi antara kandungan hara nitrogen perkebunan karet dengan band tunggal dan indeks vegetasi dari citra GeoEye-1, Sentinel-2A dan Landsat 8 OLI karena variasi kandungan nitrogen antar sampel tidak terlalu tinggi dan tidak terdapat blok tanaman yang tanpa pemupukan nitrogen yang digunakan sebagai blok kontrol. Penelitian sebelumnya untuk estimasi kandungan hara nitrogen pada tanaman jagung dan gandum dilakukan dengan cara membuat variasi dosis pemupukan nitrogen yang tinggi antar blok tanaman dan membuat blok kontrol tanpa pemupukan nitrogen (Bausch \& Khosla, 2010; Jia et al., 2011; Hunt et al., 2013).

Tabel 3. Hasil uji korelasi dan regresi band tunggal dan indeks vegetasi terbaik dengan kandungan hara nitrogen perkebunan karet

Table 3. Correlation and regression test results of a single band and the best of vegetation index with nitrogen nutrient content of rubber plantation

\begin{tabular}{cclccc}
\hline No. & \multicolumn{1}{c}{$\begin{array}{c}\text { Citra } \\
\text { Images }\end{array}$} & \multicolumn{1}{c}{$\begin{array}{c}\text { Masukan } \\
\text { Input }\end{array}$} & $\begin{array}{c}\text { Model regresi } \\
\text { Regresison model }\end{array}$ & $\mathrm{r}$ & $\mathrm{R}^{2}$ \\
\hline 1 & Landsat 8 & Band Tunggal (NIR) & $\mathrm{E}$ & 0,42 & 0,17 \\
2 & Sentinel-2A & Indeks Vegetasi Asli 10 m (CI) & $\mathrm{C}$ & 0,60 & 0,36 \\
3 & Sentinel-2A & Indeks Vegetasi Asli 20 m (NDRE 1) & $\mathrm{Q}$ & 0,51 & 0,26 \\
4 & Sentinel-2A & $\begin{array}{l}\text { Indeks Vegetasi Resampling 20 m } \\
\text { (NDRE 2a) }\end{array}$ & $\mathrm{E}$ & 0,40 & 0,16 \\
5 & GeoEye-1 & $\begin{array}{l}\text { Indeks Vegetasi Resampling 6 m } \\
\text { (OSAVI) }\end{array}$ & $\mathrm{E}$ & 0,47 & 0,22 \\
& & & & \\
\hline
\end{tabular}

Keterangan (Remaks) : Cubic (C), Exponential (E), Quadratic (Q) 


\section{Estimasi Kandungan Hara Nitrogen Perkebunan Karet}

Model regresi terbaik pada Tabel 3 digunakan untuk membuat model estimasi kandungan hara perkebunan karet. Rumus regresi masing-masing citra tersebut meliputi :

1. GeoEye- 1 resampling $6 \mathrm{~m}$ dengan indeks vegetasi OSAVI

$\mathrm{y}=5,122 \mathrm{e}^{-1,905(x)}$

2. Sentinel-2A resolusi spasial $10 \mathrm{~m}$ dengan indeks vegetasi $\mathrm{CI}$

$y=(-8,202)+6,536(x)-1,245\left(x^{2}\right)+$ $0,075\left(x^{3}\right)$

3. Sentinel-2A resolusi spasial $20 \mathrm{~m}$ dengan indeks vegetasi NDRE 1

$\mathrm{y}=(-23,232)+79,587(\mathrm{x})-60,879\left(\mathrm{x}^{2}\right)$

4. Sentinel-2A resampling $20 \mathrm{~m}$ dengan indeks vegetasi NDRE $2 \mathrm{a}$

$\mathrm{y}=1,770 \mathrm{e}^{3,850(x)}$

5. Landsat 8 OLI dengan band tunggal NIR $y=6,312 e^{-2,434(x)}$

Keterangan (Remaks) :

$\mathrm{Y}=$ Kandungan hara nitrogen perkebunan hasil estimasi

$\mathrm{X}=$ Indeks vegetasi yang digunakan
Peta hasil estimasi kandungan nitrogen perkebunan karet pada lokasi penelitian dibuat berdasarkan model regresi terbaik pada masing-masing citra dengan menggunakan rumus nomor 5 - 9 . Selanjutnya dilakukan uji akurasi model estimasi dan hasilnya dapat dilihat pada Gambar 3. Hasil uji akurasi model tersebut menunjukkan bahwa akurasi tertingi dihasilkan dengan model menggunakan indeks vegetasi NDRE 2a (menggunakan band Red-Edge 2 dan NIR) dari citra Sentinel-2A. Hasil penelitian sebelumnya juga menunjukkan bahwa indeks vegetasi NDRE memiliki akurasi yang tinggi dengan nilai SE terendah dibandingkan indeks vegetasi lainnya yang diuji untuk mengestimasi kandungan hara nitrogen pada tanaman gandum (Magney et al., 2016). Hasil penelitian Kamal et al. (2015) menunjukkan bahwa ukuran kanopi dominan vegetasi berpengaruh terhadap pemilihan ukuran piksel citra yang akan digunakan. Peta hasil model estimasi terbaik disajikan pada Gambar 4 dan peta klasifikasi kandungan hara nitrogen disajikan pada Gambar 5. Dari peta klasifikasi tersebut dapat dilihat bahwa pada lokasi penelitian didominasi kandungan hara nitrogen yang rendah $(<3,30 \%)$.

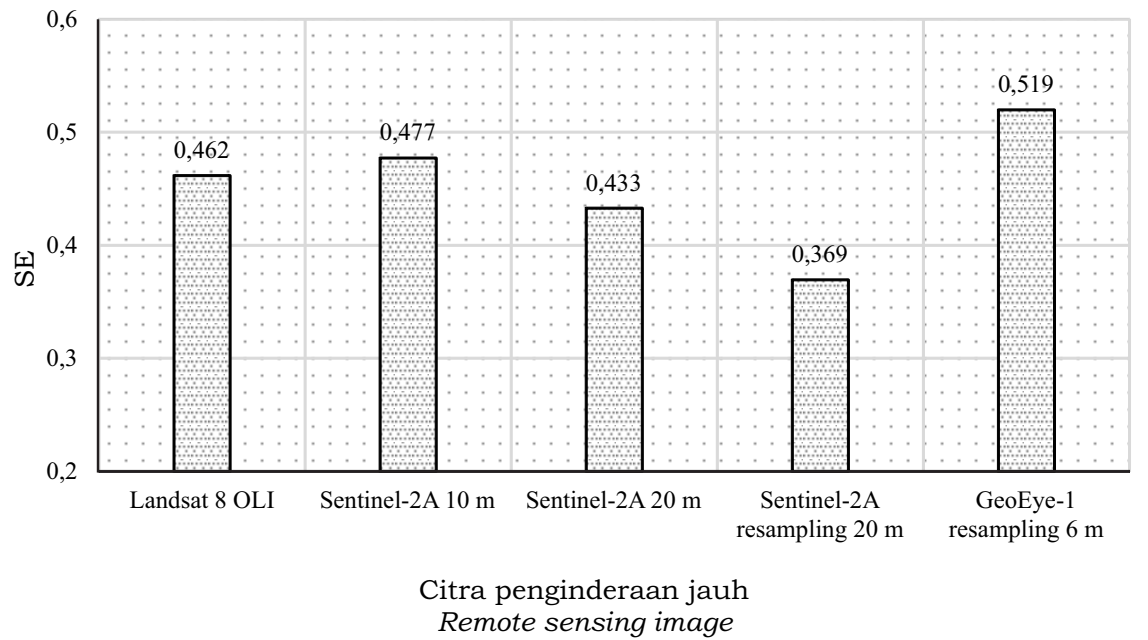

Gambar 3. Hasil uji akurasi model estimasi kandungan nitrogen tiap citra Figure 3. Test result accuracy model estimation of nitrogen content of each image 


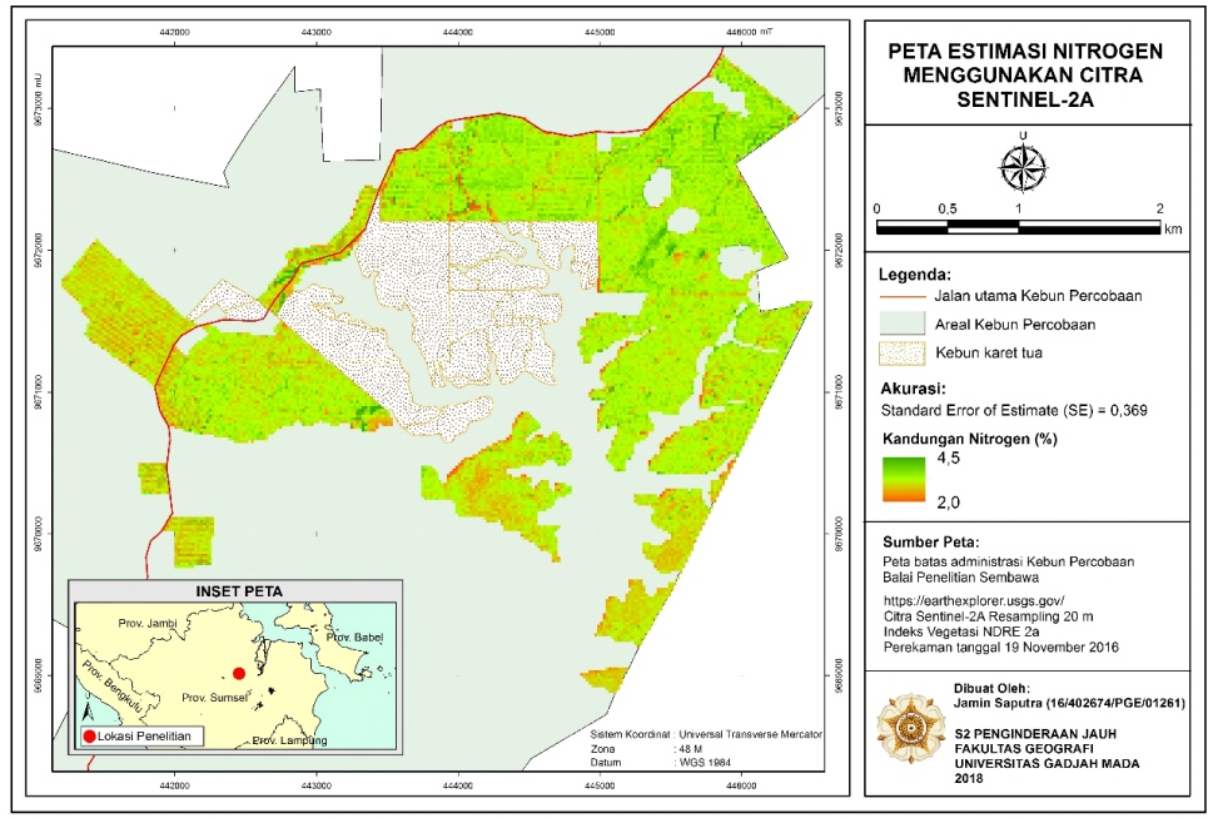

Gambar 4. Peta estimasi kandungan hara nitrogen menggunakan citra Sentinel-2A Figure 4. Map of estimated nitrogen content using Sentinel-2A image

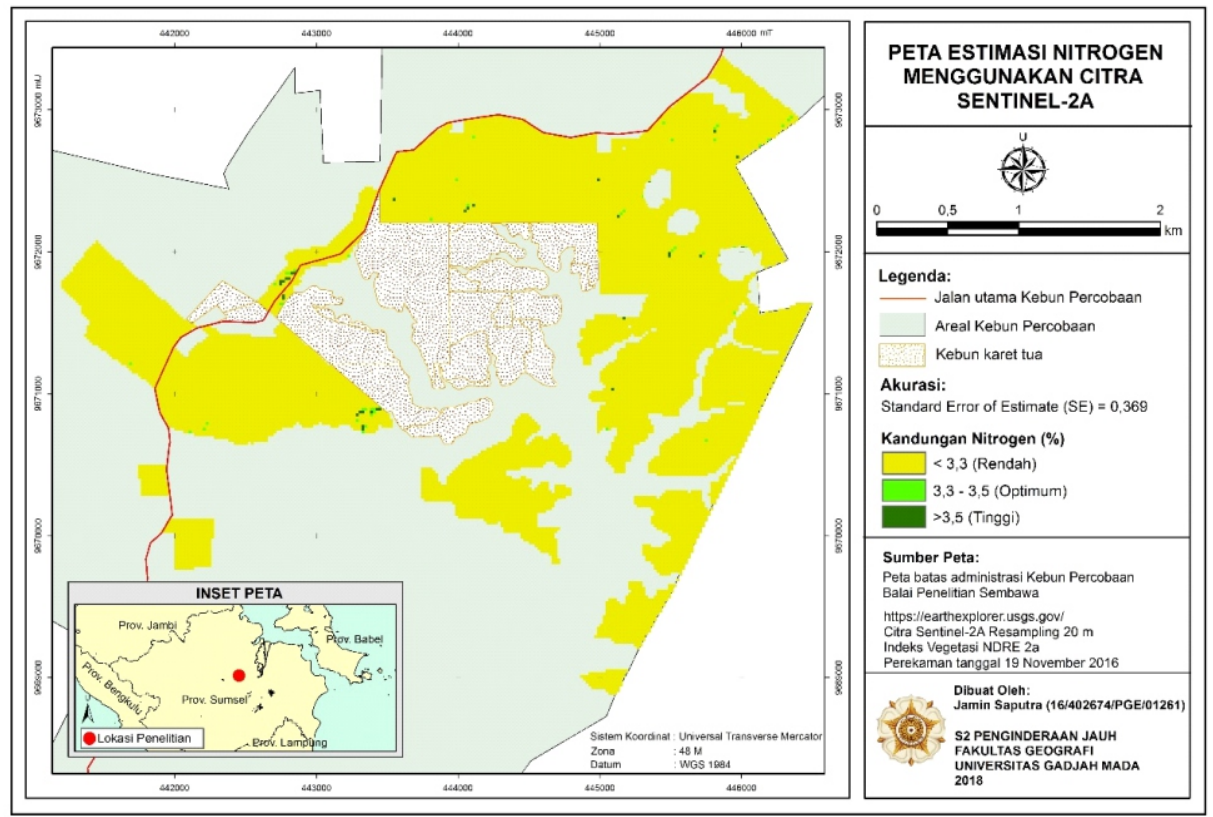

Gambar 5. Peta klasifikasi kandungan nitrogen menggunakan citra Sentinel-2A Figure 5. Map classification of nitrogen content using image Sentinel-2A 


\section{KESIMPULAN}

Kesimpulan yang dapat ditarik dari hasil penelitian adalah peta hasil estimasi kandungan hara nitrogen perkebunan karet di lokasi penelitian menggunakan citra Sentinel-2A dengan indeks vegetasi NDRE 2a (SE 0,369) memiliki akurasi yang lebih tinggi dibandingkan menggunakan citra GeoEye-1 (SE 0,519) dan Landsat 8 OLI (SE 0,462). Keunggulan citra Sentinel-2A dibandingkan dengan citra GeoEye-1 dan Landsat 8 OLI adalah memiliki band Red Edge yang lebih sensitif terhadap kandungan klorofil tanaman. Pengaruh resolusi spasial citra menunjukkan semakin tinggi resolusi spasial citra tidak memberikan peningkatan akurasi pemetaan kandungan hara nitrogen perkebunan karet.

\section{UCAPAN TERIMA KASIH}

Penulis mengucapkan terima kasih kepada Direktur Pusat Penelitian Karet dan Kepala Balai Penelitian Sembawa yang telah memberi kesempatan untuk melanjutkan jenjang pendidikan S2 di Program Studi Penginderaan Jauh Fakultas Geografi UGM. Penulis mengucapkan banyak terima kasih kepada Bapak Muhammad Kamal, M.GIS., Ph.D., dan Dr. Pramaditya Wicaksono, M.Sc., atas bimbingannya. Penulis juga mengucapkan banyak terima kasih pada Digital Globe Foundation yang telah menyediakan data citra GeoEye-1 dan USGS (United States Geological Survey) melalui website https://earthexplorer.usgs.gov/ telah menyediakan data citra Sentinel-2A dan Landsat 8 OLI pada lokasi penelitian.

\section{DAFTAR PUSTAKA}

Adiwiganda, Y.T., Hardjono, A., Manurung, A., Sihotang, U.T.B.D., Sudiharto., Goenadi, D. H., \& Sihombing, H. (1994). Teknik penyusunan rekomendasi pemupukan tanaman karet. In Forum Komunikasi Karet (pp. 1-17). Sembawa, Indonesia: Pusat Penelitian Karet.

Badan Standarisasi Nasional. (2011). SNI 7724:2011; Pengukuran dan penghitungan cadangan karbon Pengukuran lapangan untukpenaksiran cadangan karbon hutan. Jakarta, Indonesia: BSN.
Balai Penelitian Tanah. (2009). Petunjuk teknis analisis kimia tanah, tanaman, air dan pupuk. Jakarta, Indonesia: Badan Penelitian dan Pengembangan Pertanian, Departemen Pertanian.

Baret, F., Houlès, V., \& Guérif, M. (2007). Quantification of plant stress using remote sensing observations and crop models: the case of nitrogen management. Journal of Experimental Botany, 58(4), 869-880. Doi : $10.1093 / \mathrm{jxb} / \mathrm{er} 231$

Basso, B., Fiorentino, C., Cammarano, D., \& Schulthess, U. (2016). Variable rate nitrogen fertilizer response in wheat using remote sensing. Precision Agriculture, 17(2), 168-182. Doi : $10.1007 / \mathrm{s} 11119-015-9414-9$

Bausch, W.C., \& Khosla, R. (2010). QuickBird satellite versus groundbased multi-spectral data for estimating nitrogen status of irrigated maize. Precision Agriculture, 11, 274-290. Doi : 10.1007/s11119-009-9133-1

Chavez, P.S. (1996). Image-based atmospheric corrections-revisited and improved. Photogrammetric Engineering \& Remote Sensing, 62(9), 1025-1036.

Daughtry, C.S., Walthall, C.L., Kim, M.S., Brown De Colstoun, E., \& McMurtrey, J.E. (2000). Estimating corn leaf chlorophyll concentration from leaf and canopy reflectance. Remote Sensing of Environment, 74(2), 229-239. Doi : 10.1016/S0034-4257(00)00113-9

Direktorat Jenderal Perkebunan. (2016). Statistik Perkebunan Indonesia, Karet 2015-2017. Jakarta, Indonesia: Ditjenbun.

European Space Agency. (2015). Sentinel-2 user handbook. Paris, France: European Space Agency.

Gabungan Perusahaan Karet Indonesia. (2014). Bulletin Karet : Data ekspor karet alam Indonesia menurut jenis mutu periode Desember 2013. Jakarta, Indonesia: Gapkindo

G e o Ey e. (2009). Ge o Ey e-1, instrument/product description. Thornton, US: GeoEye. 
Gitelson, A.A., \& Merzlyak, M.N. (1994). Spectral reflectance changes associated with autumn senes-cence of Aesculus hippocastanum L. and Acer platanoides L. Leaves. Spectral features and relation to chlorophyll estimation. Journal of Plant Physiology, 143(3), 286-292. Doi : 10.1016/S0176-1617(11)81633-0

Gitelson, A.A., Kaufman, Y.J., \& Merzlyak, M.N. (1996). Use of a green channel in remote sensing of global vegetation from EOS-MODIS. Remote Sensing of the Environment, 58(3), 289-298. Doi : 10.1016/S0034-4257(96)00072-7

Gitelson, A.A., Gritz, Y., \& Merzlyak, M.N. (2003). Relationships between leaf chlorophyll content and spectral reflectance and algorithms for nondestructive chlorophyll assessment in higher plant leaves. Journal of Plant Physiology, 160(3), 271-282. Doi : 10.1078/0176-1617-00887

Haboudane, D., Miller, J.R., Tremblay, N., Zarco-Tejadad, P.J., \& Dextrazec, L. (2002). Integrated narrow-band vegetation indices for prediction of crop chlorophyll content for application to precision agriculture. Remote Sensing of Environment, 81(2-3), 416-426. Doi : 10.1016/S0034-4257(02)00018-4

Hunt, J. E. R., Doraiswamy, P. C., McMurtrey, J. E., Daughtry, C. S. T., \& Perry, E. M. (2013). A visible band index for remote sensing leaf chlorophyll content at the canopy scale. International Journal of Applied Earth Observation and Geoinformation, 21,

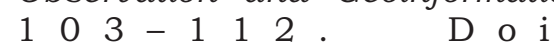
10.1016/j.jag.2012.07.020

Indranada, H. K. (1994). Pengelolaan kesuburan tanah. Jakarta, Indonesia: Bumi Aksara.

Jia, L., Yu, Z., Li, F., Gnyp, M., Koppe, W., Bareth, G., \& Zhang, F. (2011). Nitrogen status estimation of winter wheat by using an Ikonos satellite image in the North China plain. In D. Li \& Y. Chen (Eds.), 5th Computer and Computing Technologies in Agriculture (CCTA) (pp. 174-184). Beijing, Cina: Springer.
Kamal, M., Wicaksono, P., Anggara, D. W., \& Hafizt, M. (2015). Pengaruh resolusi spasial citra penginderaan jauh terhadap estimasi leaf area index mangrove di Kepulauan Karimunjawa Jawa Tengah. In $\mathrm{P}$. Wicaksono, $\mathrm{M}$. Kamal, S. Lestari, I. Wicaksono, D. Setiady, \& A. B. Arundina (Eds.), Simposium Nasional Sains Geoinformasi IV 2015 (pp. 667-674). Yogyakarta, Indonesia : PUSPICS Fakultas Geografi UGM

Kuester, M. A. (2017). Absolute radiometric calibration: $2016 v 0$. US: Digital Globe.

Lichtenthaler, K., \& Welburn, A. R. (1983). Determination of Total Carotenoids and Chlorophylls A and B of Leaf Extracts in Different Solvents. Biochemical Society Transactions, 11(5), 591-592. Doi : $10.1042 /$ bst0110591

Magney, T.S., Eitel, J.U.H., \& Vierling, L.A. (2016). Mapping wheat nitrogen uptake from RapidEye vegetation indices. Precision Agriculture, 17, 1-23. Doi : 10.1007/s11119-016-9463-8

Rondeaux, G., Steven, M., \& Baret, F. (1996). Optimization of soil-adjusted vegetation indices. Remote Sensing and Environment, 55(2), 95-107. Doi : 10.1016/0034-4257(95)00186-7

Rosmarkam, A., \& Yuwono, N.W. (2002). Ilmu kesuburan tanah. Yogyakarta, Indonesia: Kanisius.

Sudihart.o, Susetyo, I., \& Setyawan, B. (2006). Pedoman Pengambilan contoh tanah dan daun di perkebunan karet. Salatiga, Indonesia: Balai Penelitian Getas.

Sugiyono. (2014). Statistik untuk penelitian. Bandung, Indonesia: Alfabeta.

Thomas, \& Hidayati, U. (2003). Tinjauan pemupukan pada tanaman karet menghasilkan. Warta Pusat Penelitian Karet, 22(2-3), 41-50.

Tucker, C.J. (1979). Red and photographic infrared linear combinations for monitoring vegetation. Remote Sensing of Environment, 8(2), 127-150. Doi : 10.1016/0034-4257(79)90013-0 
United States Geological Survey. (2016). Landsat 8 (L8) data users handbook, version 2.0. Sioux Falls, South Dakota: Earth Resources Observation and Science (EROS) Center.

Updike, T., \& Comp, C. (2010). Radiometric use of WorldView-2 imagery. Colorado, USA: Digital Globe.

Wicaksono, P. (2017). Mangrove aboveground carbon stock mapping of multiresolution passive remote-sensing systems. International Journal of Remote Sensing, 38(6), 1551-1578. Doi : 10.1080/01431161.2017.1283072

Wicaksono, P., \& Hafizt, M. (2017). Dark target effectiveness for dark-object subtraction atmospheric correction method on mangrove above-ground carbon stock mapping. IET Image Processing, 12(4), 582-587. Doi : 10.1049/iet-ipr.2017.0295
Wijaya, T., Ardika, R., \& Saputra, J. (2014). The effect of omission fertilizer application on rubber yield of PB 260. Current Agriculture Research Journal, 2 ( 2$), 68-72$. 6 o i : 10.12944/CARJ.2.2.01

Yoder, B.J., \& Pettigrew-Crosby, R.E. (1995). Predicting nitrogen and chlorophyll content and concentrations from reflectance spectra $(400-2500 \mathrm{~nm})$ at leaf and canopy scales. Remote Sensing of Environment, 53(3), 199-211. Doi : 10.1016/0034-4257(95)00135-N 